\title{
Android Based Dictionary Application of Agricultural Terms in Bali
}

\author{
Dwi Putra Githa \\ Department of Information \\ Technology \\ Faculty of Engineering \\ Udayana University \\ Badung, Bali, Indonesia
}

\author{
Desy Purnami Singgih Putri \\ Department of Information \\ Technology \\ Faculty of Engineering \\ Udayana University \\ Badung, Bali, Indonesia
}

\author{
IGD. Gita Purnama Arsa Putra \\ Department of Balinese \\ Language \\ Faculty of Arts \\ Udayana University \\ Denpasar, Bali, Indonesia
}

\begin{abstract}
Bali is one of the islands in Indonesia which is famous for its natural and cultural beauty. Cultural preservation, especially in Bali, is needed to keep the ancestral heritage and Balinese identity. Culture in agriculture is one of the cultures in Bali that must be preserved. The agricultural terms in Bali is diverse and has its own uniqueness. One way to preserve culture in agriculture is to develop a dictionary application for the agricultural terms in Bali based on Android. It is hoped that this application can introduce and preserve culture especially in agriculture in Bali to the general public. Considering the technological developments that most people already use smartphones, an android based application is developed so that it can facilitate access to applications via a smartphone.
\end{abstract}

Keywords: Android, Culture, Cultural Conservation, Dictionary, Agricultural Terms.

\section{INTRODUCTION}

Culture is a complex which includes knowledge, beliefs, art, morals, customs and other abilities and habits possessed by humans as part of society [1]. Cultural preservation, especially in Bali, is needed to maintain the ancestral heritage and identity of Bali and the Indonesian people more broadly.

Culture in agriculture is one of the cultures in Bali that must be preserved. Bali is an island in Indonesia where most of the land is used in agriculture. According to data from the Central Statistics Agency Bali, 2018 regarding land area according to its use in the Province of Bali in 2017, the area of agricultural land in Bali is 407534 ha, $72 \%$ of the total land in Bali [2]. The terms in agriculture in Bali are diverse and have their own uniqueness. One way to preserve culture in agriculture is to develop an Android-based dictionary of agricultural terms in Bali.

Android is an operating system based on Linux for cellular phones such as smartphones and tablet computers. Android provides an open platform for developers to create their own applications for use by a variety of mobile devices. At present most smartphone vendors have produced Android-based smartphones, including HTC, Motorola, Samsung, LG, Sony Ericsson, Acer, Nexus, Oppo, and Vivo.

From the above background, research was conducted to design and build a dictionary of agricultural terms in Bali based on Android. It is expected that this application can introduce and preserve culture, especially in agriculture in Bali to the general public. Considering the development of technology that most of the people already use smartphones, an android-based application was developed to facilitate access to application.

\section{LITERATURE REVIEWS}

Based on previous research related to the Android-based dictionary application from a journal entitled "Android-based Mobile Application Dictionary of Computer Terms" in 2014 compiled by Herlan Mulyana and Maimunah stated that the Computer Glossary Dictionary was created because the need for information is very important and a difficult time when having to look for meaning words or terms using conventional print dictionaries [3]. The 2016 "Android Based Geography Dictionary Application Research" compiled by Winda Yormala and Kurnia Setiawati created an application that has the term geography, equipped with solar system information, exercises according to solar system material and admin to update dictionaries and materials [4].

\section{RESEARCH METHODS}

\subsection{Research Flow}

Figure 1 is the stage of the research conducted. The first stage of this research is defining the problems want to solve. After defining the problems, the next step is to collect data to support the resolution of the existing problems. After the required data is collected, the data is analyzed as a basis for making an application. The stages of making an application consist of designing databases, interfaces, and making program code. The next step is to inputing sample data to test the system. If the system produces outputs that are not as expected, data analysis will be performed again. If the results are as expected, the research phase has been completed. 


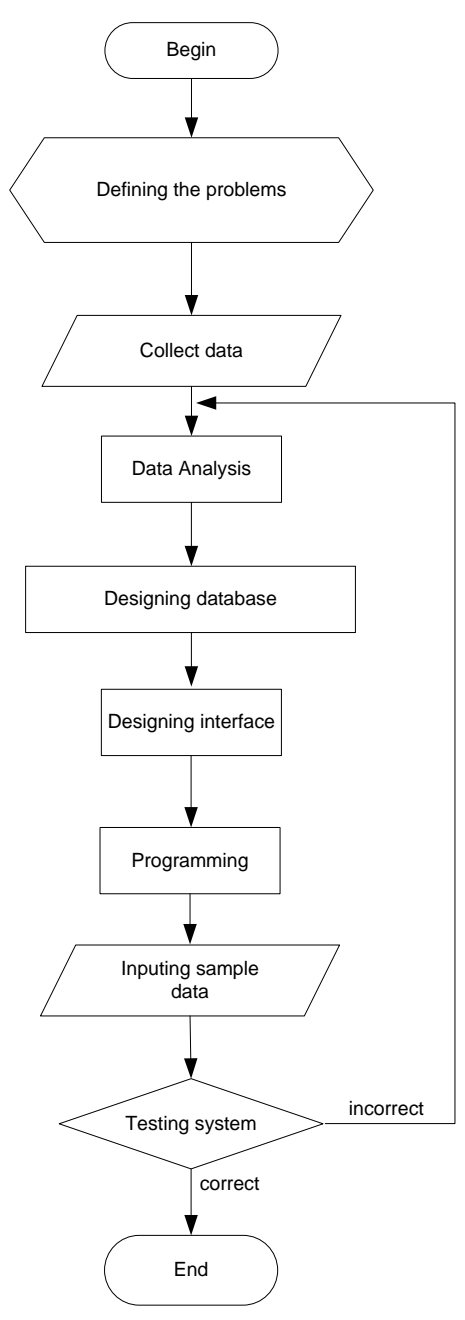

Figure. 1 Research flow

\subsection{Overview}

Figure 2 is a overview of the system being built. The initial input of the system is the agricultural terms in Bali, then the system will request the agricultural term data in the database. Data about the agricultural term requested by the user will be forwarded to the dictionary application of agricultural terms in Bali. Information on agricultural terms in Bali is accepted by users in Indonesian and English.

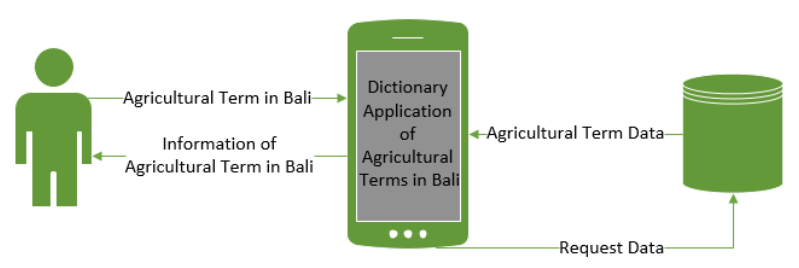

Figure. 2 Overview system

\section{CONCEPTS AND THEORIES}

This section contains concepts and theories that support theresearch. They are including Android, Android Studio, PHP, and MySQL.

\subsection{Android}

Android is a developed operating system for Linux-based mobile devices such as smart phones and tablet computers [5].
Android includes an operating system, middleware, and applications. Android Inc. is a name of a company engaged in the world of information and communication technology, the company was bought by a giant company, namely Google Inc. and the Handset Alliance was formed, a consortium of 34 hardware, software and telecommunications companies including: Google, HTC, Intel, Motorola, Qualcomm, TMobile and Nvidia.

\subsection{Android Studio}

Android Studio is the official Integrated Development Environment (IDE) for Android app development, based on IntelliJ IDEA . On top of IntelliJ's powerful code editor and developer tools, Android Studio offers even more features that enhance your productivity when building Android apps.[6]

\subsection{PHP}

PHP is a scripting language that can be embedded or inserted into HTML. PHP is widely used for dynamic website programming [7]. PHP stands for PHP hypertext preprocessor which is used as a server-side script language in web development that is inserted in an html document [8]. The use of PHP allows the web to be made dynamic so that the maintenance of the website becomes easier and more efficient.

\subsection{MySQL}

MySQL is an open source DBMS (Database Management System). The advantage of MySQL is that the database can work on various platforms and is easy to access [9]. MySQL uses the standard query language SQL (Structure Query Language).

\section{RESULT AND IMPLEMENTATION}

\subsection{Requirements Analysis}

Requirement analysis is carried out to determine the functional requirements of the Dictionary of Agricultural Terms in Bali. The following in Table 1 are system requirements.

Table 1. System requirements

\begin{tabular}{|r|l|}
\hline No. & \multicolumn{1}{|c|}{ Requirements } \\
\hline 1 & The system can display a list of agricultural terms. \\
\hline 2 & $\begin{array}{l}\text { The system can display information and pictures / } \\
\text { photos (if any) about agricultural terms. }\end{array}$ \\
\hline 3 & $\begin{array}{l}\text { The system can search agricultural terms } \\
\text { according to user input. }\end{array}$ \\
\hline 4 & $\begin{array}{l}\text { The system can provide a system admin menu to } \\
\text { manage data in agricultural terms. }\end{array}$ \\
\hline 5 & $\begin{array}{l}\text { The system can validate the system admin } \\
\text { username and password. }\end{array}$ \\
\hline
\end{tabular}

\subsection{Data}

Based on observations and documentation, 200 data on agricultural terms in Bali are obtained, Table 2 is an example of agricultural term data in Bali. 
Table 2. Example of agricultural terms data in Bali

\begin{tabular}{|c|c|c|}
\hline No. & Terms & Description \\
\hline 1. & $\begin{array}{l}\text { Abangan/ } \\
\text { Blangu }\end{array}$ & $\begin{array}{l}\text { Conduit made of bamboo, areca } \\
\text { nut or areca palm tree trunks; } \\
\text { function to channel water from } \\
\text { one place to another; tree trunks } \\
\text { used depend on the volume of } \\
\text { water, the greater the volume the } \\
\text { greater the trunk is used. }\end{array}$ \\
\hline 2. & Aét & $\begin{array}{l}\text { Clue when people plow so the } \\
\text { cow turns left. }\end{array}$ \\
\hline 3. & Andog & $\begin{array}{l}\text { Fertile soil; usually still flowing } \\
\text { water, muddy, and rarely dry. }\end{array}$ \\
\hline 4. & Andungan & $\begin{array}{l}\text { The first water channel from a } \\
\text { water source (Temuku) that } \\
\text { flows through the fields. }\end{array}$ \\
\hline 5. & Anggapan & $\begin{array}{l}\text { Knives for cutting rice or cutting } \\
\text { during harvest; flat shaped; the } \\
\text { size of a hand grip; the edges are } \\
\text { filled with wood or bamboo } \\
\text { which functions to hold the tool. }\end{array}$ \\
\hline 6. & Anggas & $\begin{array}{l}\text { The name of the poison } \\
\text { grasshopper; thorns or barriers } \\
\text { that are placed in such a way as } \\
\text { to close access and protect the } \\
\text { coconut or other plants from } \\
\text { being stolen. }\end{array}$ \\
\hline 7. & Bangkil & $\begin{array}{l}\text { Tools used to harvest rice in } \\
\text { fields. }\end{array}$ \\
\hline 8. & Camok & $\begin{array}{l}\text { Mouth cover animals such as } \\
\text { cow or buffalo. }\end{array}$ \\
\hline 9. & Dapak & $\begin{array}{l}\text { Cutting tools for branches, } \\
\text { wood, twigs, and roots; made of } \\
\text { iron }\end{array}$ \\
\hline 10. & Gabag & $\begin{array}{l}\text { Agricultural tools in the form of } \\
\text { rakes that are used in rice fields, } \\
\text { made of wood, function to } \\
\text { destroy or crush the soil to } \\
\text { become smooth, as well as } \\
\text { leveling the soil so that water } \\
\text { can be flooded evenly on each } \\
\text { plot of paddy. }\end{array}$ \\
\hline
\end{tabular}

\subsection{Use Case Diagram}

The Dictionary of Agricultural Terms in Bali involves two actors: system administrator and user. Application functionality consists of login, managing data on agricultural terms, displaying a list of agricultural terms, searching for agricultural terms, and displaying the information of agricultural terms. The use case diagram can be seen in Figure 3.

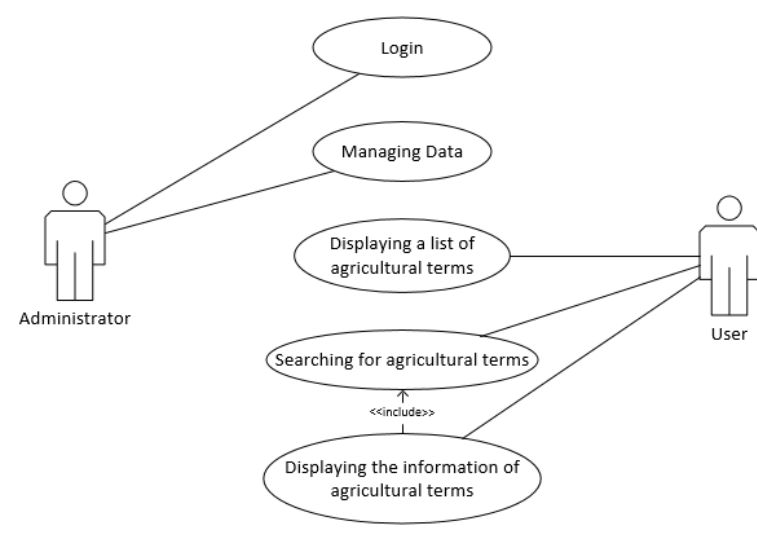

Figure. 3 Use case diagram

\subsection{Database Design}

The Dictionary of Agriculture Terms in Bali uses a table in the database used. The table is used to store data on the name of the term, the description of the term in Indonesian, the term description in English, the picture of the term and the publish status of the term. The table structure used in the database can be seen in Table 3 .

Table 3. Table structure

\begin{tabular}{|l|l|}
\hline \multicolumn{1}{|c|}{ Field } & \multicolumn{1}{c|}{ Data Type } \\
\hline id & int \\
\hline bali_word & varchar(50) \\
\hline ina_desc & text \\
\hline eng_desc & text \\
\hline img & varchar(50) \\
\hline is_publish & tinyint \\
\hline
\end{tabular}

\subsection{System Interface}

\subsubsection{User}

The application can be accessed by users using smartphones that use the Android operating system. The user application display can be seen in Figure 4. The user in using the application chooses one of the terms available to see the description and picture of the agricultural term. Users can also search for agricultural terms by typing keywords in the search field. 


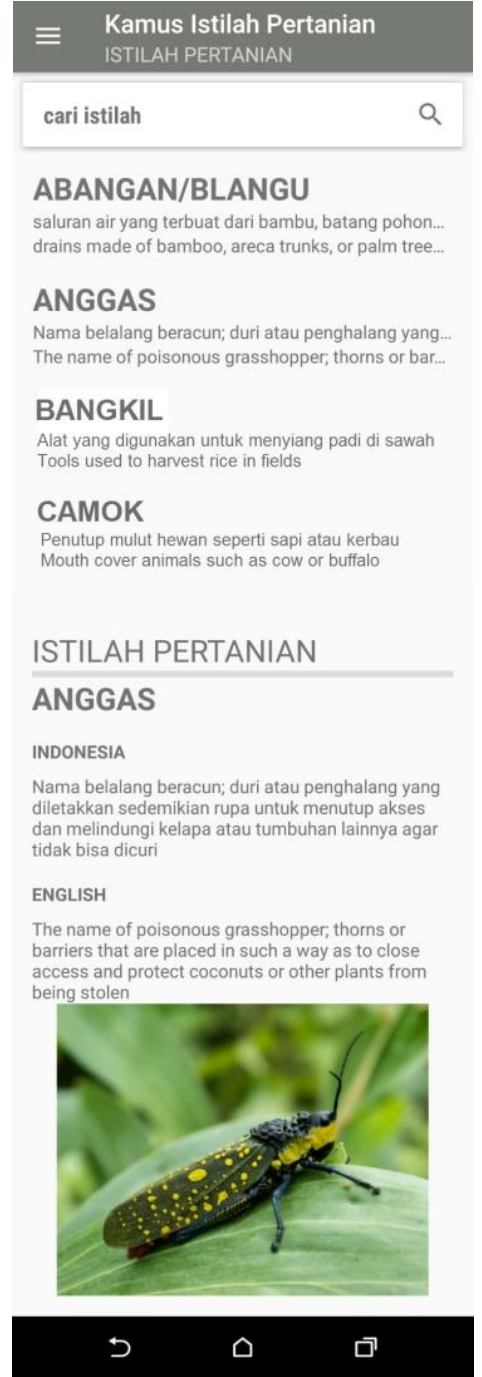

Figure. 4 User interface

\subsubsection{Administrator}

The process of updating data can be done by the system administrator using the administrator menu. On the administrator menu, the administrator can add the agricultural terms data, change the agricultural terms data and delete the agricultural terms data. Data will be synchronized with data on the Android application. The administrator menu is created using PHP so it is web based. The administrator display menu can be seen in Figure 5 .

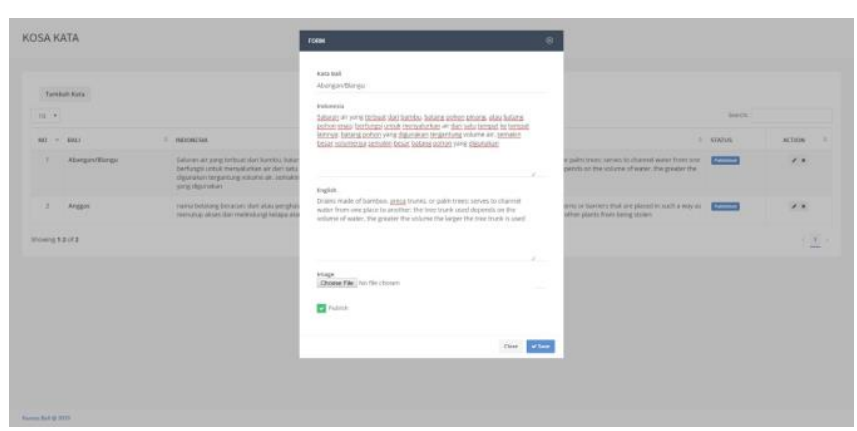

Figure. 5 Administrator interface

\subsection{Black Box Testing}

Black box testing is done by trying the functions / menus provided by the application. Details of the test can be seen in Table 4.

Table 4. Black box testing

\begin{tabular}{|c|c|c|c|c|}
\hline No & Functional & Scenario & Result & $\begin{array}{c}\text { Conclusi } \\
\text { on }\end{array}$ \\
\hline 1. & Login & $\begin{array}{l}\text { User } \\
\text { enters } \\
\text { correct } \\
\text { username } \\
\text { and } \\
\text { password. }\end{array}$ & $\begin{array}{l}\text { User } \\
\text { successfully } \\
\text { logged in as } \\
\text { administrator. }\end{array}$ & Correct \\
\hline 2. & Login & $\begin{array}{l}\text { User } \\
\text { entered } \\
\text { wrong } \\
\text { username } \\
\text { or } \\
\text { password. }\end{array}$ & $\begin{array}{l}\text { The system } \\
\text { displays an } \\
\text { incorrect } \\
\text { username or } \\
\text { password } \\
\text { message. The } \\
\text { user failed to } \\
\text { log on as an } \\
\text { administrator. }\end{array}$ & Correct \\
\hline 3. & $\begin{array}{l}\text { Displaying } \\
\text { a list of } \\
\text { agricultural } \\
\text { terms. }\end{array}$ & $\begin{array}{l}\text { The user } \\
\text { enters the } \\
\text { applicatio } \\
\text { n. }\end{array}$ & $\begin{array}{l}\text { The system } \\
\text { displays a list } \\
\text { of agricultural } \\
\text { terms. }\end{array}$ & Correct \\
\hline 4. & $\begin{array}{l}\text { Displaying } \\
\text { information } \\
\text { about the } \\
\text { explanation } \\
\text { of } \\
\text { agricultural } \\
\text { terms. }\end{array}$ & $\begin{array}{l}\text { The user } \\
\text { chooses } \\
\text { one } \\
\text { agricultur } \\
\text { al term. }\end{array}$ & $\begin{array}{l}\text { The system } \\
\text { displays } \\
\text { information } \\
\text { on selected } \\
\text { agricultural } \\
\text { terms in } \\
\text { Indonesian } \\
\text { and English. }\end{array}$ & Correct \\
\hline 5. & $\begin{array}{l}\text { Searching } \\
\text { for } \\
\text { agricultural } \\
\text { terms. }\end{array}$ & $\begin{array}{l}\text { The user } \\
\text { enters the } \\
\text { term he } \\
\text { wants to } \\
\text { search for. }\end{array}$ & $\begin{array}{l}\text { The system } \\
\text { displays the } \\
\text { agricultural } \\
\text { term sought. }\end{array}$ & Correct \\
\hline 6. & $\begin{array}{l}\text { Adding } \\
\text { agricultural } \\
\text { term data. }\end{array}$ & $\begin{array}{l}\text { Administr } \\
\text { ator clicks } \\
\text { the } \\
\text { 'Tambah } \\
\text { Kata' } \\
\text { button, } \\
\text { then } \\
\text { enters all } \\
\text { data fields } \\
\text { and clicks } \\
\text { the 'Save' } \\
\text { button. }\end{array}$ & $\begin{array}{l}\text { The system } \\
\text { stores data on } \\
\text { agricultural } \\
\text { terms } \\
\text { according to } \\
\text { what the } \\
\text { administrator } \\
\text { input into the } \\
\text { database. }\end{array}$ & Correct \\
\hline 7. & $\begin{array}{l}\text { Changing } \\
\text { the } \\
\text { agricultural } \\
\text { term data. }\end{array}$ & $\begin{array}{l}\text { The } \\
\text { administra } \\
\text { tor clicks } \\
\text { the pencil } \\
\text { marked } \\
\text { button on } \\
\text { one of the } \\
\text { agricultur } \\
\text { al terms, } \\
\text { then } \\
\text { changes } \\
\text { the data } \\
\text { and clicks } \\
\text { the 'Save' }\end{array}$ & $\begin{array}{l}\text { The system } \\
\text { changes the } \\
\text { agricultural } \\
\text { term data in } \\
\text { the database. }\end{array}$ & Correct \\
\hline
\end{tabular}




\begin{tabular}{|c|l|l|l|l|}
\hline & & button. & & \\
\hline 8. & Deleting & The & The system & Correct \\
& agricultural & administra & deletes & \\
& term data. & tor clicks & agricultural & \\
& & the button & term data & \\
& marked & from the & \\
& with a & database. & \\
& cross on & & \\
& one of the & & \\
& data & & \\
& agricultur & & \\
& al terms. & & \\
& & & \\
\hline
\end{tabular}

\section{CONCLUSION}

The design and build of an Android-based Dictionary of Agricultural Terms in Bali has been successfully implemented. All application functionality is running as expected. Application design and development begins with analyzing application requirements, then making application designs using use case diagrams, making database designs according to application requirements and creating interface designs. After the design is finished, proceed with making the program code, then entering the sample data and testing all the functionalities of the agricultural term dictionary application in Bali.

\section{REFERENCES}

[1] Hawkins, P. 2012. Creating a Coaching Culture. New York: Open University Press.

[2] https://bali.bps.go.id/statictable/2018/04/11/72/luaslahan-per-kabupaten-kota-menurut-penggunaannya-diprovinsi-bali-2017.html, diakses pada tanggal 1 Maret 2019.

[3] Mulyana, Herlan \& Maimunah. 2014. Aplikasi Mobile Kamus Istilah Komputer Berbasis Android. Jurnal Penelitian Ilmu Komputer, System Embedded \& Logic, Vol. 1, No.2, Hal. 27-34.

[4] Yormala, Winda \& Setiawati, Kurnia. 2016. Perancangan Aplikasi Kamus Geografi Berbasis Android. Jurnal TEKNOIF, Vol. 4, No. 1, Hal. 48-56.

[5] I W.A. Krisna, I N. Piarsa, and P. W. Buana. 2019. Android-Based High School Management Information System. International Journal of Computer Applications Technology and Research, Volume 8-Issue 11, 415-419.

[6] https://developer.android.com/studio/intro, diakses pada tanggal 1 Agustus 2020.

[7] Pursana, P. E. 2014. Sistem Informasi Koperasi Modul Simpanan Berbasis Android Terintegrasi Berbasis Web. Merpati, 2(1), 67-78.

[8] Peranginangin, Kasiman. 2006. Aplikasi WEB dengan PHP dan MySQL. Yogyakarta: Andi Offset.

[9] A. Hanafi, I. M. Sukarsa, and A. A. K. A. C. Wiranatha. 2017. Pertukaran Data Antar Database dengan Menggunakan Teknologi API. Lontar Komputer, vol. 8, no. 1 , pp. 22-30. 